\title{
Characterization of Canna yellow mottle virus in a New Host, Alpinia purpurata, in Hawaii
}

\author{
Jingxin Zhang, Kishore K. Dey, Birun Lin, Wayne B. Borth, Michael J. Melzer, Diane Sether, Yanan Wang, I-Chin Wang, \\ Huifang Shen, Xiaoming Pu, Dayuan Sun, and John S. Hu
}

First, third, ninth, tenth, and eleventh authors: Key Laboratory of New Technique for Plant Protection in Guangdong, Institute of Plant Protection, Guangdong Academy of Agricultural Sciences, Guangzhou, China; first, second, fourth, fifth, sixth, seventh, eighth, and twelfth authors: Department of Plant and Environmental Protection Sciences, College of Tropical Agriculture and Human Resources, University of Hawaii, Honolulu; and seventh author: College of Plant Protection, Agricultural University of Hebei, Baoding, China.

Accepted for publication 14 February 2017.

\begin{abstract}
Canna yellow mottle virus (CaYMV) is an important badnavirus infecting Canna spp. worldwide. This is the first report of CaYMV in flowering ginger (Alpinia purpurata) in Hawaii, where it is associated with yellow mottling and necrosis of leaves, vein streaking, and stunted plants. We have sequenced CaYMV in A. purpurata (CaYMV-Ap) using a combination of next-generation sequencing and traditional Sanger sequencing techniques. The complete genome of CaYMV-Ap was 7,120 bp with

an organization typical of other Badnavirus species. Our results indicated that CaYMV-Ap was present in the episomal form in infected flowering ginger. We determined that this virus disease is prevalent in Hawaii and could potentially have significant economic impact on the marketing of $A$. purpurata as cut flowers. There is a potential concern that the host range of CaYMV-Ap may expand to include other important tropical plants.
\end{abstract}

Flowering ginger, Alpinia purpurata (Vieill.) K. Schum., produces small white flowers subtended by large, showy, red or pink bracts. It belongs to the diverse tropical plant family Zingiberaceae (Illg and Faria 1995). In Hawaii (United States), it is grown as an ornamental plant in landscapes and for its cut flowers, which had a commercial value of \$1.6 million in 2005 and 2006 (Paret et al. 2008). In previous studies, we have found Banana bract mosaic virus (BBrMV) infecting A. purpurata on Oahu, where it causes leaf mosaic and streaking (Wang et al. 2010; Zhang et al. 2016). However, other virus-like symptoms distinct from those produced by BBrMV were also observed on some plants, suggesting the presence of more than one virus.

Recent advances in next-generation sequencing (NGS) have made possible the detection of new infectious plant viruses in the genera Closterovirus (Melzer et al. 2013), Begomovirus (Idris et al. 2014), and Ampelovirus (Marais et al. 2014), as well as Betaflexivirus (Elbeaino et al. 2014). Information generated by NGS includes all nucleic acids present in the plant genome and also those from any infecting viruses, highlighting the value of NGS for virus discovery (Marais et al. 2015). This approach was used by us to search for other viruses that may coinfect $A$. purpurata in addition to BBrMV. NGS revealed sequences most similar to Canna yellow mottle virus (CaYMV; family Caulimoviridae, genus Badnavirus). We also detected CaYMV-like sequences in several $A$. purpurata plants that were not infected by any other plant viruses. These plants showed symptoms typical of CaYMV infections in Canna species, strongly suggesting that a CaYMV-like agent was associated with the severe symptoms in infected plants.

CaYMV was first reported infecting Canna spp. in Japan (Yamashita et al. 1979) before it was found in the United States (Lockhart 1988; Yamashita et al. 1985). The disease is now found

Corresponding author: J. Hu; E-mail address: johnhu@hawaii.edu

*The $\boldsymbol{e}$-Xtra logo stands for "electronic extra" and indicates that two supplementary files and two supplementary figures are published online.

(c) 2017 The American Phytopathological Society worldwide including in Italy, the Netherlands (Marino et al. 2008), India (Kumari et al. 2014), and Kenya (Agneroh et al. 2015). On the U.S. mainland, CaYMV infects Canna indica in several states, including Florida (Momol et al. 2004) and Washington (Pappu et al. 2008). The disease on Canna spp. causes substantial yellow mottling and necrosis of the foliage with chlorotic and necrotic vein streaking (Lockhart 1988). These foliar symptoms may often be combined with streaking on the stems and flowers (Marino et al. 2008). Stunting has been associated with infections by this virus (Yamashita et al. 1985), as has yellow vein mosaic of betel vine (Piper betel) in India (Kumari and Raj 2015).

CaYMV has not been reported previously infecting plants in Hawaii, nor has A. purpurata been reported previously as a host. This is the first report of CaYMV infecting any plants in Hawaii. In this study, we characterized the complete genome of CaYMV in A. purpurata and determined its phylogenetic placement among known badnaviruses. We also determined that the episomal form of this CaYMV isolate was associated with the severe symptoms on A. purpurata. This information may lead to a more effective, knowledgebased management of the disease in Hawaii. For the sake of discussion, we will refer to the CaYMV isolate in A. purpurata as CaYMV-Ap in this manuscript.

\section{MATERIALS AND METHODS}

Virus characterization. Leaves of $A$. purpurata with virus-like symptoms were collected from the same site on the University of Hawaii at Manoa campus in Honolulu where BBrMV was first found in 2009 (Wang et al. 2010; Zhang et al. 2016). Double-stranded RNAs (dsRNAs) from symptomatic leaves were isolated and used to synthesize cDNA (Melzer et al. 2010) following the procedures of Morris and Dodds (1979) as modified by Hu et al. (1993). The doublestranded cDNA library was generated using the dsRNA templates as described by Zhang et al. (2016). Size-fractionated PCR products were directly sequenced on an NGS machine, the Ion PGM System (Ion 314 Chip, ThermoFisher Scientific, MA), at the University of Hawaii's Advanced Studies of Genomics, Proteomics, and Bioinformatics 
Laboratory (ASGPB). Short-length ( $<65 \mathrm{nt}$ ) and low-quality reads and primer sequences were trimmed, as were low-quality basecalls at the ends of reads. The remaining high-quality reads were assembled using the de-novo assembly program in GeneiousPro 7.1.5 (Biomatters Ltd., Auckland, New Zealand), and the assembled contig sequences subjected to BLAST analysis against nucleotide sequences in NCBI.

Whole genome sequencing of CaYMV-Ap. To determine the complete genome sequence of this DNA virus, 12 primer pairs (Table 1) were designed based on a contig sequence from NGS and were used to amplify overlapping fragments spanning the whole genome. Total DNA was isolated with the DNeasy Plant Mini Kit (Qiagen), according to the manufacturer's instructions. PCR amplifications were carried out in 20- $\mu \mathrm{l}$ reactions containing $1.0 \mu \mathrm{l}$ of DNA template and $10 \mu \mathrm{l}$ of reaction mixture with Phusion High-Fidelity DNA Polymerase (New England Biolabs) and $1.0 \mu \mathrm{l}$ forward/reverse primers each at $10 \mu \mathrm{M}$. The mixture was incubated at $98^{\circ} \mathrm{C}$ for $3 \mathrm{~min}$, followed by 35 cycles of amplification at $98^{\circ} \mathrm{C}$ for $30 \mathrm{~s}, 55^{\circ} \mathrm{C}$ for $30 \mathrm{~s}$, $68^{\circ} \mathrm{C}$ for $60 \mathrm{~s}$, with a final extension at $68^{\circ} \mathrm{C}$ for $10 \mathrm{~min}$. PolyA-tails were added by PCR using Taq DNA polymerase and dATP and the amplicons were then ligated into pGEM-T Easy. The cloned PCR products were Sanger-sequenced at ASGPB.

Phylogenetic analysis. Thirty-eight complete genome sequences of Badnavirus (Supplementary File S1) were retrieved from NCBI for phylogenic analysis using Cauliflower mosaic virus (CaMV, GenBank accession NC_001497.1) as the out-group. All sequences were aligned using ClustalW (Higgins et al. 1994). Phylogenetic analysis was performed with Mega 5.0 (Tamura et al. 2011) using maximum likelihood algorithms boot-strapped with 1,000 replications. We also performed a phylogenetic analysis using amino acid sequences from open reading frame (ORF)3 of CaYMV-Ap and multiple badnavirus sequences (Supplementary File S2) together with the out-group, Rice tungro bacilliform virus (RTBV, NC_001914.1).

CaYMV-Ap and BBrMV detection by PCR and RT-PCR. Universal primer pair BadnaFP/RP for detecting viruses of the genus
Badnavirus (Yang et al. 2003) and the specific primers pair CaYMV-3/4 (Momol et al. 2004) were used to detect CaYMV-Ap from the plants in this study. We also developed the specific primer pair CaYMV1931/2598, which can discriminate CaYMV-Ap from other badnaviruses, such as Taro bacilliform virus (Supplementary Fig. S1). Twenty microliters of PCR reaction conditions were assembled as follows: $10 \mu \mathrm{l}$ of $2 \times$ GoTaq Green master mix (Promega), $0.5 \mu \mathrm{l}$ of forward/reverse primers each at $10 \mu \mathrm{M}, 1.0 \mu \mathrm{l}$ of DNA, and $8 \mu \mathrm{l}$ of nanopure $\mathrm{H}_{2} \mathrm{O}$. The cycling program was as follows: $95^{\circ} \mathrm{C}$ for $5 \mathrm{~min}$; 30 cycles at $95^{\circ} \mathrm{C}$ for $30 \mathrm{~s}, 55^{\circ} \mathrm{C}$ for $30 \mathrm{~s}, 72^{\circ} \mathrm{C}$ for $1 \mathrm{~min}$; and then $72^{\circ} \mathrm{C}$ for $10 \mathrm{~min}$.

To detect CaYMV-Ap by RT-PCR, the specific primer pair CaYMV-1931/2598 was used. The potyvirus-specific primer pair NIb2F/3R (Zheng et al. 2008; Zhang et al. 2016) was used to detect BBrMV by RT-PCR. Total RNA was isolated using the NucleoSpin RNA Plant Kit (Macherey-Nagel, Germany) including DNase treatment, according to the manufacturer's instructions. First-strand cDNA synthesis was initiated with $2 \mu \mathrm{l}$ of DNase-treated RNAs and $1.0 \mu \mathrm{l}$ of random primers $(50 \mathrm{ng} / \mu \mathrm{l})$ (Promega), heated at $70^{\circ} \mathrm{C}$ for $5 \mathrm{~min}$, and then quenched on ice. Then, $5 \mu \mathrm{l}$ of M-MLV $5 \times$ reaction buffer (Promega), $5 \mu \mathrm{l}$ of dNTPs $(2.5 \mu \mathrm{M}$ each), $0.5 \mu \mathrm{l}$ of recombinant RNasin ribonuclease inhibitor $(40 \mathrm{U} / \mu \mathrm{l})$, and $1.0 \mu \mathrm{l}$ of M-MLV reverse transcription $(200 \mathrm{U} / \mu \mathrm{l})$ were added and the reaction brought to a final volume of $25 \mu \mathrm{l}$ with nuclease-free water. This assembled reaction was incubated for $60 \mathrm{~min}$ at $37^{\circ} \mathrm{C}$. The PCR reaction conditions were as follows: $10 \mu \mathrm{l}$ of $2 \times$ GoTaq Green master mix (Promega), $0.5 \mu \mathrm{l}$ of forward/reverse primers each at $10 \mu \mathrm{M}, 1.0 \mu \mathrm{l}$ of cDNA, and $8 \mu \mathrm{l}$ of nanopure $\mathrm{H}_{2} \mathrm{O}$. The cycling program was as follows: $95^{\circ} \mathrm{C}$ for $5 \mathrm{~min}$; 35 cycles at $95^{\circ} \mathrm{C}$ for $30 \mathrm{~s}, 55^{\circ} \mathrm{C}$ for $30 \mathrm{~s}$, and $72^{\circ} \mathrm{C}$ for $1 \mathrm{~min}$; and then $72^{\circ} \mathrm{C}$ for $10 \mathrm{~min}$.

Transmission electron microscopy (TEM). Leaf samples from symptomatic $A$. purpurata plants that tested positive for CaYMV-Ap with PCR were examined by TEM using either the leaf-dip method or a modified partial purification method (Ahlawat

TABLE 1. Primers used for virus detection, and Sanger sequencing including overlapping fragments cloning and subsequencing

\begin{tabular}{|c|c|c|c|}
\hline Primer & Sequence & Use & Reference \\
\hline BadnaFP & 5'-ATGCCITTYGGIAARAAYGCICC-3' & Badnavirus detection & Yang et al. 2003 \\
\hline BadnaRP & 5'-CCAYTTRCAIACISCICCCCAICC-3' & Badnavirus detection & Yang et al. 2003 \\
\hline CaYMV-3 & 5'-GACTTCCTGGGTGCAACAAT-3' & CaYMV detection & Momol et al. 2004 \\
\hline CaYMV-4 & 5'-TCTGTGCAATCTTGGCGTAG-3' & CaYMV detection & Momol et al. 2004 \\
\hline CaYMV-1931 & 5'-TGCTGGAACACTGGCTTTCA-3' & CaYMV detection & This study \\
\hline CaYMV-2598 & 5'-ССТСТТСАТСССССАССАAC-3' & CaYMV detection & This study \\
\hline $\mathrm{NIb} 2 \mathrm{~F}$ & 5'-GTITGYGTIGAYGAYTTYAAYAA-3' & Potyvirus detection & Zheng et al. 2008 \\
\hline NIb3R & 5'-TCIACIACIGTIGAIGGYTGNCC-3' & Potyvirus detection & Zheng et al. 2008 \\
\hline CaYMV-1F (6172) & 5'-GTGGCATCTGCAAGTGGAAG-3' & Sanger sequencing & This study \\
\hline CaYMV-1R (6872) & 5'-GCCCCAACGACACCATAACT-3' & Sanger sequencing & This study \\
\hline CaYMV-2F (5627) & 5'-GAATGCACCTGCGGTTTTCC-3' & Sanger sequencing & This study \\
\hline CaYMV-2R (6331) & 5'-TCTGATTGTGAGCGCCTTCT-3' & Sanger sequencing & This study \\
\hline CaYMV-3F (4907) & 5'-AAGCCTCGAAGGTGGAGTTC-3' & Sanger sequencing & This study \\
\hline CaYMV-3R (5656) & $5^{\prime}$-СCСССТАAAACAACCGTCCA-3' & Sanger sequencing & This study \\
\hline CaYMV-4F (4276) & 5'-CCCGAGACGAGATCAAGCAAT-3' & Sanger sequencing & This study \\
\hline CaYMV-4R (4989) & 5'-GAGGCCACAGTGAATGCCT-3' & Sanger sequencing & This study \\
\hline CaYMV-5F (3707) & 5'-CAAATGCTATGCGTGCGGAG-3' & Sanger sequencing & This study \\
\hline CaYMV-5R (4405) & 5'-CTTGTTTTTGGCCTGCTCCT-3' & Sanger sequencing & This study \\
\hline CaYMV-6F (3036) & 5'-AAGAACTTCCCGACAGCCG-3' & Sanger sequencing & This study \\
\hline CaYMV-6R (3808) & 5'-CACCACCTCCATTCCGTCTT-3' & Sanger sequencing & This study \\
\hline CaYMV-7F (2469) & 5'-CTCGTGGCATTCCTGGATGT-3' & Sanger sequencing & This study \\
\hline CaYMV-7R (3247) & 5'-GTAAGCGGCATCCTGGGTTA-3' & Sanger sequencing & This study \\
\hline CaYMV-8F (1787) & 5'-AGAACGTATGCTGGTGCTCG-3' & Sanger sequencing & This study \\
\hline CaYMV-8R (2653) & 5'-TCCGAATTGCTTGGACTCGT-3' & Sanger sequencing & This study \\
\hline CaYMV-9F (1104) & 5'-ACTAGCGGCGACAACTCAAG-3' & Sanger sequencing & This study \\
\hline CaYMV-9R (1863) & 5'-ACGTACTCGAATCCTGCCCT-3' & Sanger sequencing & This study \\
\hline CaYMV-10F (463) & 5'-TCGGAGGACGAACTAGGACA-3' & Sanger sequencing & This study \\
\hline CaYMV-10R (1256) & 5'-AACTTGTCGTCGAGAGAGGC-3' & Sanger sequencing & This study \\
\hline CaYMV-11F (6951) & 5'-CCCTCTCGTTGCTAGGCAT-3' & Sanger sequencing & This study \\
\hline CaYMV-11R (678) & 5'-AGGTCGTTACGATAACACAGAA-3' & Sanger sequencing & This study \\
\hline CaYMV-12F (6490) & 5'-ACGTTCTCGCCGATACACTG-3' & Sanger sequencing & This study \\
\hline CaYMV-12R (279) & 5'-TATACGGCTTCCTCGCCTTC-3' & Sanger sequencing & This study \\
\hline
\end{tabular}


et al. 1996). Five-gram leaf samples were powdered in liquid nitrogen and extracted with $18 \mathrm{ml}$ of $200 \mathrm{mM}$ phosphate buffer. The extract was filtered through cheesecloth and centrifuged at $12,000 \times g$ for $10 \mathrm{~min}$ and the pellet discarded. Triton $\mathrm{X}-100$ was added to the supernatant to a final concentration of $2 \%$ and the mixture was layered over a $5-\mathrm{ml}$ cushion of $30 \%$ sucrose in $100 \mathrm{mM}$ phosphate buffer, $\mathrm{pH} 7.2$, and centrifuged for $1 \mathrm{~h}$ at 100,000 $\times \mathrm{g}$ in a Beckman type 70Ti rotor. The pellets were resuspended in $100 \mu \mathrm{l}$ of $10 \mathrm{mM}$ phosphate buffer and $150 \mathrm{mM} \mathrm{NaCl}, \mathrm{pH}$ 7.2. The suspension was clarified by shaking briefly with $50 \mu \mathrm{l}$ of chloroform, followed by centrifuging for 6 min at $12,400 \times g$. The upper aqueous phase was examined by TEM after staining in $1 \%$ uranyl acetate.

Assessment of CaYMV-Ap incidence in A. purpurata in Hawaii. To screen for CaYMV-Ap, A. purpurata plants with and without virus-like symptoms were collected from seven locations on the island of Oahu and one location on the island of Hawaii. DNA from 87 collected samples was screened by PCR using the primer pair CaYMV-3/4

\section{RESULTS}

Draft genome of CaYMV-Ap by NGS. A total of 289,674 high-quality reads were generated from the cDNA library, with a median length of $217 \mathrm{bp}$. Of these reads, 44,586 and 19,528 were both de novo assembled into contigs that mapped to the genome of BBrMV, the complete genome of which was validated to be 9,713 bp (GenBank accession KT456531) (Zhang et al. 2016). Our NGS analysis also generated another 453 high-quality reads that were de novo assembled into a contig of 6,961 bp (Fig. 1). This contig had 99\% identity to a partial gene sequence within the RT-RNase $\mathrm{H}$ region of the CaYMV polyprotein in GenBank (accessions HE774733.1 and HE774735.1). The draft genome of CaYMV-Ap is double-stranded DNA (dsDNA) and contains a gap between the termini of its noncircular contig sequence (Fig. 1). To confirm that the CaYMV-Ap sequence is indeed present in the symptomatic $A$. purpurata plants, we used the universal primer pair BadnaFP/RP and the specific primer pair CaYMV-3/4 to

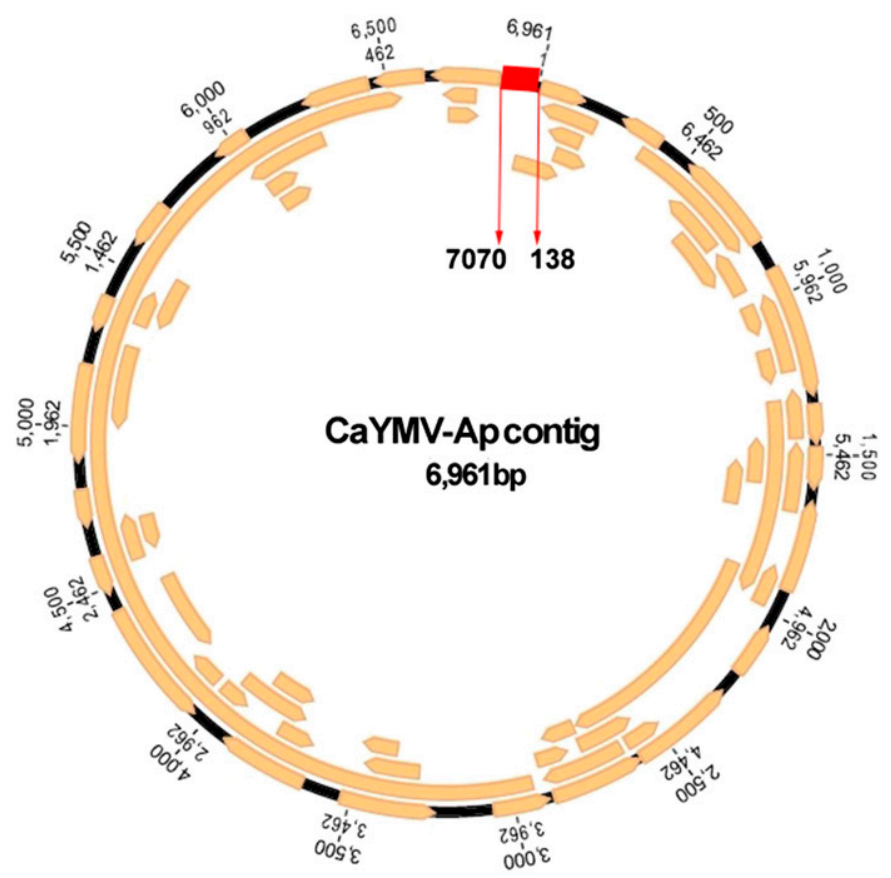

Fig. 1. Sequence coverage of the Canna yellow mottle virus (CaYMV)-Ap contig $(6,961 \mathrm{bp})$ revealed by next-generation sequencing and its corresponding site $\left(5^{\prime}-3^{\prime}: 138\right.$ to $\left.7,070 \mathrm{bp}\right)$ in the complete genome of CaYMV-Ap. The region at the top indicates the gap in the circular genome, and the numbers 138 and 7,070 (arrows indicating the gap termini) correspond to the sites in the complete genome of CaYMV-Ap. screen for the badnavirus in A. purpurata showing symptoms of foliar necrosis and yellow mottling. All eight symptomatic samples collected from the same site that the samples used for NGS were collected and tested positive (Fig. 2A and B).

Whole-genome sequencing and genome annotation. The complete genome sequence of CaYMV-Ap from symptomatic A. purpurata plants was assembled from NGS (6,961 bp), and completed and confirmed by Sanger sequencing of 12 overlapping PCR fragments. The complete genome $(7,210 \mathrm{bp})$ was generated and deposited in GenBank (accession number KU168312). The CaYMV-Ap genome has an organization typical of other Badnavirus species (Fig. 3), beginning with the conserved sequence (TGGTATCA GAGC) of the tRNAMET primer-binding site, followed by three predicted ORFs. The tRNAMET primer-binding site is considered the starting point for minus-strand synthesis during the replication of other badnavirus isolates (Bouhida et al. 1993). Upstream of the tRNAMET primer-binding site, a typical TATA-box (TATATAA) was found at position 6,935 to $6,941 \mathrm{bp}$. This region is considered part of the

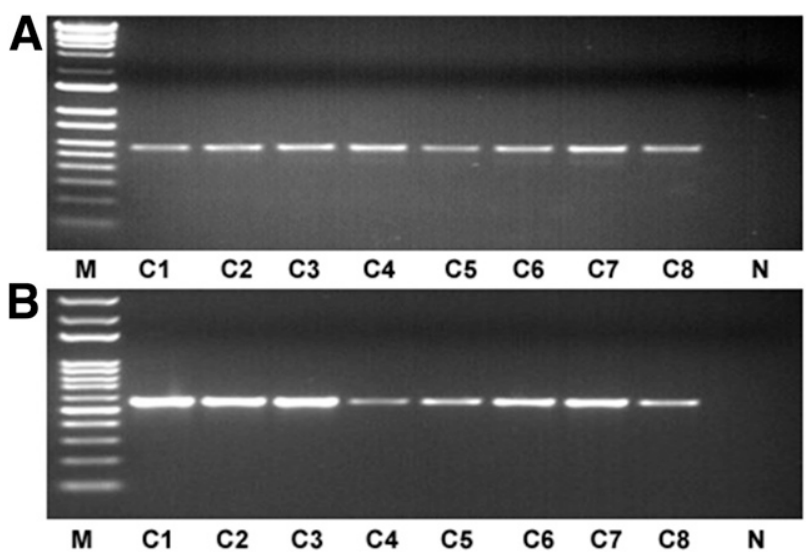

Fig. 2. PCR detection using badnavirus universal primers and Canna yellow mottle virus (CaYMV)-specific primers. A, PCR detection from eight symptomatic samples using the badnavirus universal primer pair BadnaFP/RP. B, PCR detection from eight symptomatic samples using CaYMV-specific primer pair $\mathrm{CaYMV-3/4}$. In both panels, $\mathrm{C} 1$ to $\mathrm{C} 8=$ symptomatic samples, $\mathrm{N}=$ no template control, and $\mathrm{M}=$ molecular weight markers.

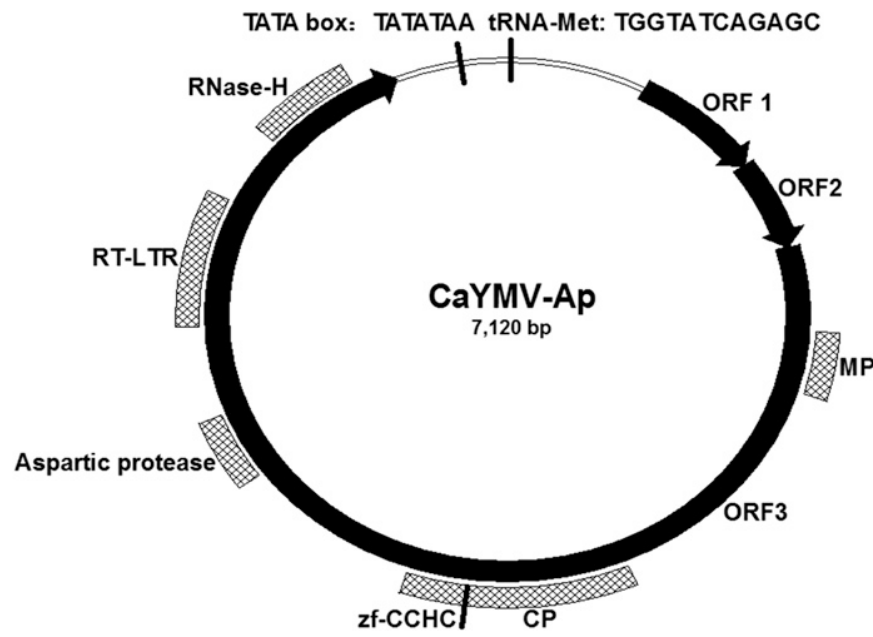

Fig. 3. Genome organization of Canna yellow mottle virus (CaYMV)-Ap. Genome replication is initiated at the tRNA ${ }^{M E T}$ primer-binding site followed by three predicted open reading frames (ORFs), and a typical TATA-box located upstream of the tRNA ${ }^{\mathrm{MET}}$ primer-binding site. A polyprotein encoded by ORF3 harbored motifs for the movement protein (MP), zf-CCHC in the coat protein $(\mathrm{CP})$, aspartic protease, reverse transcriptases (RT), and $\mathrm{RNaseH}$ domains. 
promoter region used in badnavirus replication (Medberry et al. 1992). ORF1, ORF2, and ORF3 are located at sites 542 to $1,060 \mathrm{bp}, 1,060$ to $1,461 \mathrm{bp}$, and 1,461 to $6,677 \mathrm{bp}$, respectively, with an overlap at the ends of adjoining ORFs (both junctions had the sequence TG A TG). ORF1 putatively encodes a protein of 173 amino acids with a molecular weight of $19.8 \mathrm{kDa}$; ORF2 putatively encodes a protein of 134 amino acids with a molecular weight of $14.7 \mathrm{kDa}$; and ORF3 putatively encodes a protein of 1,739 amino acids with a molecular weight of $198.5 \mathrm{kDa}$. The ORF1 protein is predicted to be in the DUF1319 super family containing a number of viral proteins of approximately 200 residues, the function of which is not known (NCBI's conserved domain database). The protein encoded by ORF2 is predicted to contain putative DNA binding sites as observed in Cacao swollen shoot virus (Jacquot et al. 1996). ORF3 encodes a polyprotein harboring motifs for the movement protein (MP; Arg127 to Arg215), zf-CCHC in the coat protein (CP; Cys749 to Asn766), aspartic protease (Ile1055 to Leu1151), reverse transcriptases (RT; Lys1278 to Gly1461), and RNaseH domains (Ile1560 to Val1687) (Fig. 3).

Phylogenetic analysis. A phylogenetic analysis was conducted using the whole genome sequences of 38 Badnavirus species (Fig. 4A), with CaMV as the out-group. The phylogenetic tree confirmed the taxonomic placement of CaYMV-Ap within the genus Badnavirus. CaYMV-Ap was most closely related to Sugarcane bacilliform virus (ScBV), Banana streak Mysore virus (BSMysV), and Pineapple bacilliform comosus virus (PBCoV). These viruses constituted a clade that also included other isolates of Banana streak virus (BSV). They showed a high genome nucleotide divergence, however, with
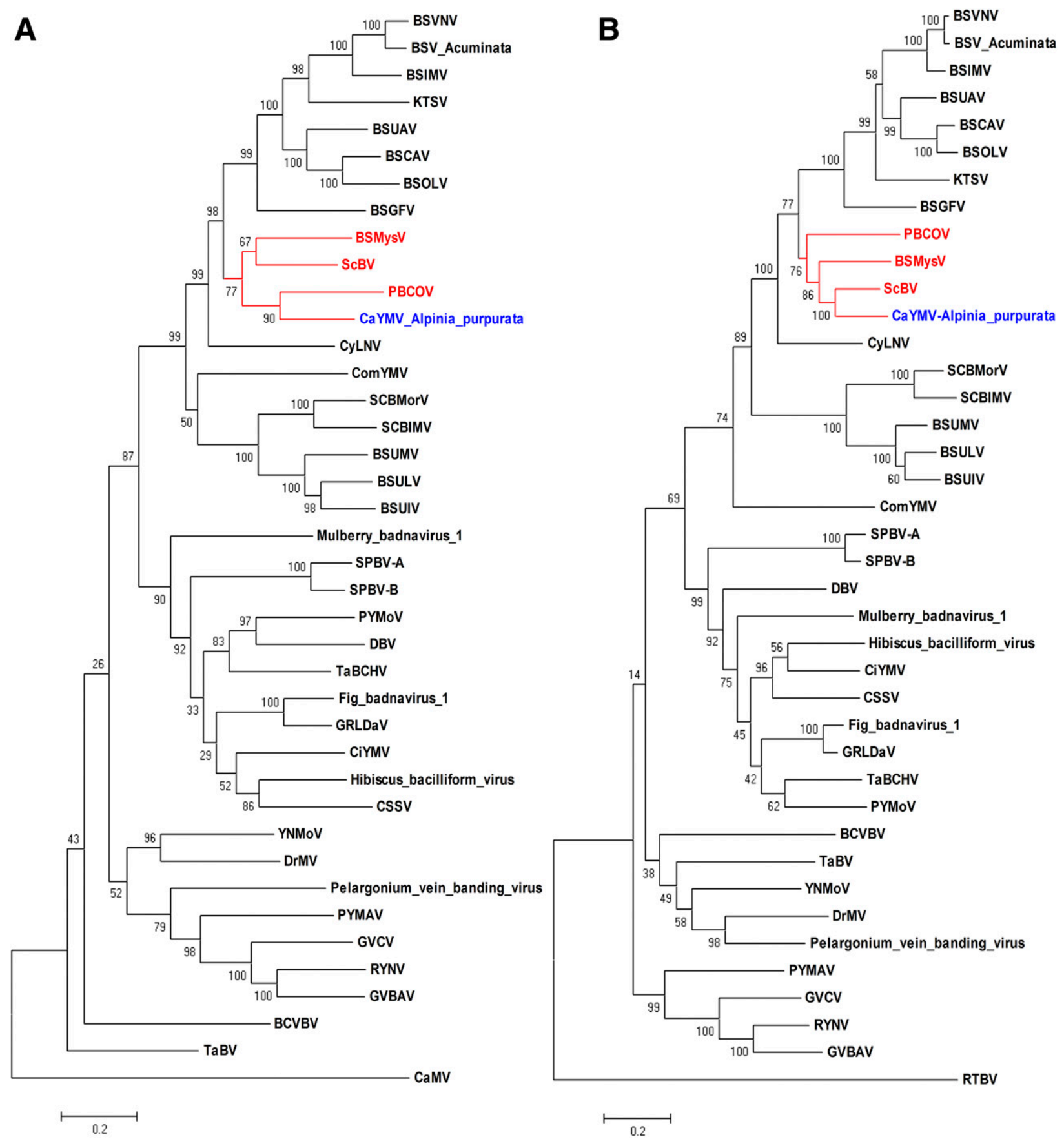

Fig. 4. Phylogenetic analyses of $\mathbf{A}$, the complete genome sequence and $\mathbf{B}$, amino acid sequences of the ORF3 polyprotein from members of the genus Badnavirus. The virus names and sequences are presented in Supplementary Files S1 and S2. The analysis used maximum likelihood algorithms bootstrapped with 1,000 replications. Numbers at nodes indicate the level of bootstrap support for each node. 
CaYMV-Ap presenting overall nucleotide identities of only 57.3, 53.1, and 50.2\% with ScBV, BSMysV, and PBCoV, respectively. ORF1 of CaYMV-Ap shared 55.5, 49.4, and 55.3\% nucleotide identity, respectively, with ScBV, BSMysV, and PBCoV; ORF2 shared $60.7,54.5$, and $43.2 \%$ nucleotide identity, respectively, with ScBV, BSMysV, and PBCoV; and ORF3 shared 64.9, 59.2, and 60.03\% nucleotide identity, respectively, with ScBV, BSMysV, and PBCoV. Within the RT-RNase H region of ORF3, CaYMV-Ap shares $76 \%$ identity with $\mathrm{ScBV}, 75 \%$ identity with $\mathrm{PBCoV}$, and $70 \%$ identity with BSMysV. A phylogenetic analysis was also conducted using the amino acid sequences of ORF3 (Fig. 4B). Again, CaYMV-Ap was most closely related to $\mathrm{ScBV}, \mathrm{BSMysV}$, and $\mathrm{PBCoV}$ using this approach.

Evidence of the episomal form of CaYMV-Ap in A. purpurata. We used PCR and RT-PCR to investigate whether CaYMV-Ap was present in the episomal form. Leaves from symptomatic plants all tested positive by PCR using the specific primer pair CaYMV-3/4 (Fig. 5A, lanes 1 to 7) and the newly designed specific primer pair CaYMV-1931/2598 (Fig. 5B, lanes 1 to 7). Asymptomatic leaves from other plants produced no amplicons even though they were collected from the same location as leaf samples that tested positive (Fig. 5A and 5B, lane H). Six of seven symptomatic samples tested positive using RT-PCR (Fig. 5C).

In addition, partially purified preparations from symptomatic A. purpurata leaves that were also used to generate the NGS contigs and tested positive for CaYMV-Ap in PCR were examined by TEM. Typical badnavirus-like bacilliform particles of approximately $120 \times$ $30 \mathrm{~nm}$ were observed (Fig. 6).

Symptoms on $A$. purpurata associated with CaYMV-Ap infections. To explore the association between disease symptoms on A. purpurata and samples that tested positive for CaYMV-Ap, we collected additional samples from the previously sampled collection sites and the other sites. Most samples from the previous collection sites tested positive for CaYMV-Ap using PCR (Fig. 5A, B, lanes 1 to 15). Of these PCR-positive samples (1 to 15), CaYMV-Ap could be detected in 13 samples using RT-PCR (Fig. 5C). Only one site (collection site 1) contained plants that were also positive for BBrMV by RT-PCR (data not shown). The CaYMV-Ap-positive samples had foliar symptoms similar to those described previously for CaYMV on Canna spp. The symptoms included yellow mottling and necrosis (Fig. 7A), and vein streaking (Fig. 7B) of leaves (Lockhart 1988). Additionally, these plants were stunted (Fig. 7C), with a reduced flower size. All asymptomatic plants (Fig. 7D) tested negative for CaYMV-Ap using PCR and RT-PCR.

Plants from the location (collection site 1) that were coinfected with BBrMV and CaYMV-Ap displayed different symptoms (Fig. 8A). Samples 1, 2, and 8 had diffuse chlorotic and necrotic spots on mottled leaves and were CaYMV-Ap positive and BBrMV negative with PCR and RT-PCR, respectively (Fig. 8B and C). Samples 9 and 10 showed foliar mosaic and streaking typical of BBrMV infections (Wang et al. 2010) and also tested BBrMV positive by RT-PCR and weakly CaYMV-Ap positive by PCR. Samples 3, 4, 11, and 12 were all positive for both CaYMV-Ap and BBrMV and displayed the most severe symptoms. These results suggested that on A. purpurata CaYMV-Ap may exacerbate the disease symptoms caused by BBrMV alone.

Assessment of CaYMV-Ap incidence in A. purpurata in Hawaii. To investigate the distribution of CaYMV-Ap in Hawaii, we collected samples of $A$. purpurata with and without CaYMV-Apassociated symptoms from the islands of Oahu and Hawaii. Plant samples from 4 of 7 locations (locations 1, 2, 3, and 7) on Oahu with severe previously described symptoms of CaYMV-Ap were positive for CaYMV-Ap in PCR analyses (Table 2). Asymptomatic plants collected from the other locations on Oahu (locations 4, 5, and 6) and the location on the island of Hawaii were negative for CaYMV-Ap in PCR analyses.

\section{DISCUSSION}

In previous work, we used dsRNA isolated from a single common green ti plant (Cordyline fruticosa L.) in Hawaii and obtained the genomes of four closely related closteroviruses (Melzer et al. 2013). In the present study, we used NGS to analyze virus infections in $A$. purpurata and were able to obtain the complete genome sequence of the potyvirus BBrMV infecting A. purpurata (Zhang et al. 2016). NGS analysis of diseased $A$. purpurata plants in Hawaii produced 289,674 sequence reads from a cDNA library generated from symptomatic plants. Unexpectedly, we found 453 reads matching the genus Badnavirus. These reads may have been produced from residual DNAs present in the dsRNA preparations since these preparations were not treated with DNase. Assembly of these reads into a large contig (6,961 bp) revealed a sequence highly similar to partial sequences of a polyprotein gene from CaYMV. We also performed rolling-circle amplification (RCA) analyses to identify circular dsDNA sequences present in the symptomatic A. purpurata plants. The RCA results revealed

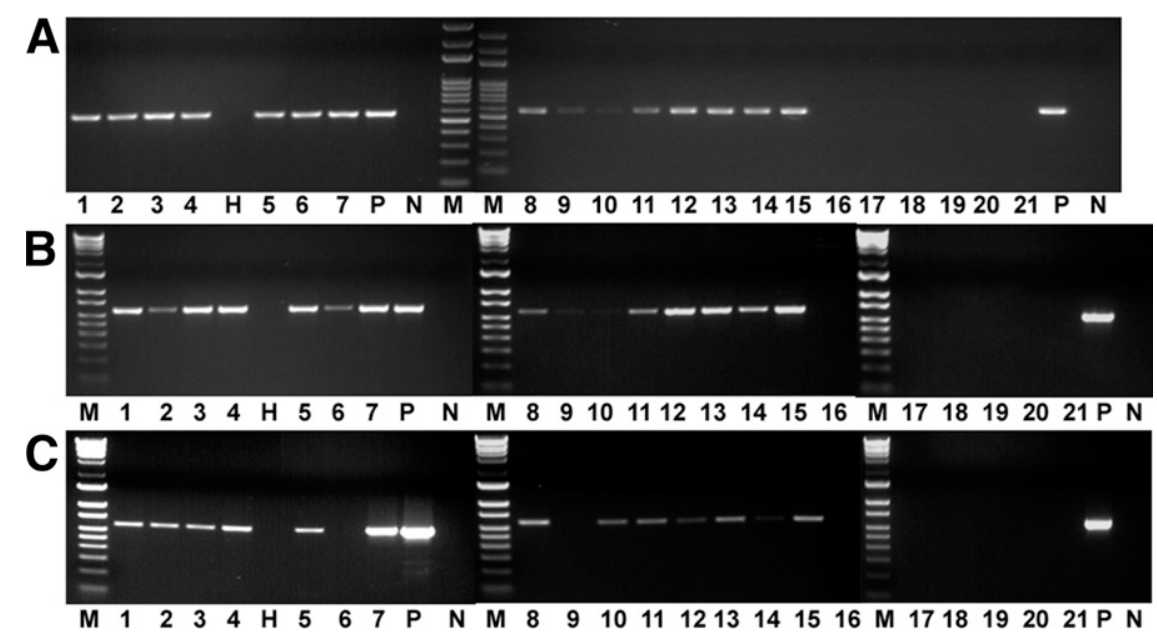

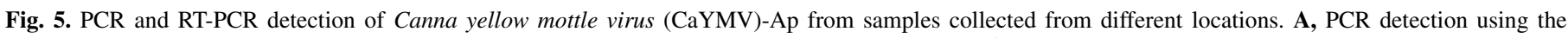

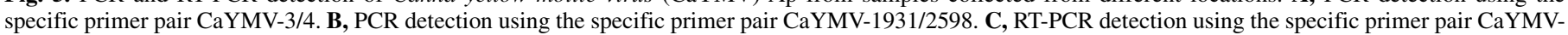

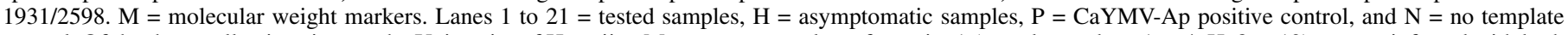

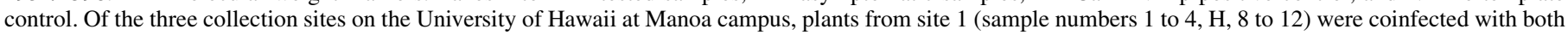

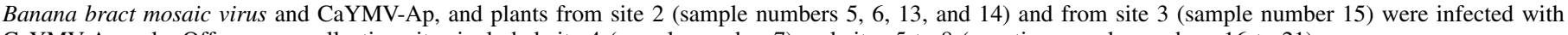
CaYMV-Ap only. Off-campus collection sites included site 4 (sample number 7) and sites 5 to 8 (negative sample numbers 16 to 21 ). 
circular fragments of about $7 \mathrm{~kb}$ in length, corresponding to the genome size of badnaviruses (data not shown). Based upon the detection of a circular double-stranded DNA sequence, we then proceeded to complete the whole genome (7,210 bp) of CaYMV-Ap by designing primers using the NGS data and filling gaps in the contig using traditional Sanger sequencing.

Typical symptoms on Canna caused by CaYMV include chlorosis, mottling, necrosis, and streaking on leaves (Lockhart 1988), as well as stunted growth (Yamashita et al. 1985). We observed a similar range of symptoms on A. purpurata in Hawaii, suggesting that the CaYMV-Ap detected might also be involved in this disease of A. purpurata. Although the presence of BBrMV coinfecting with CaYMV-Ap in some symptomatic plants complicated visual diagnosis, results of our molecular analyses indicate that CaYMV-Ap is more prevalent than

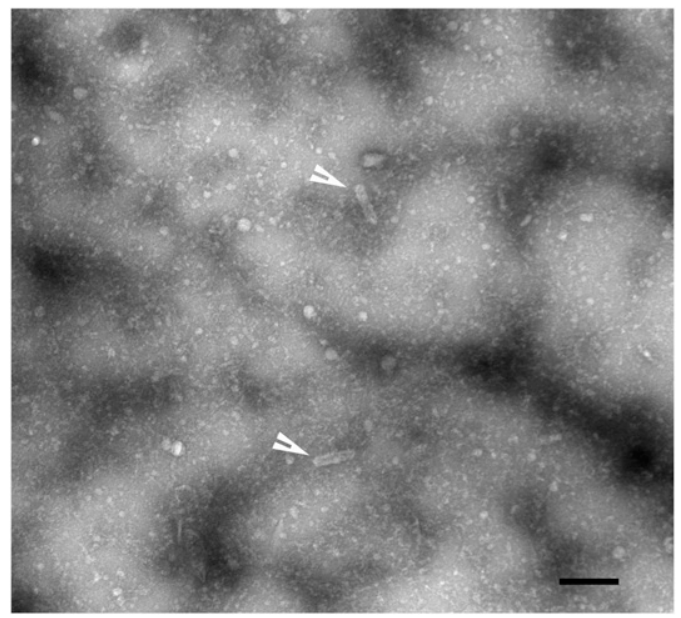

Fig. 6. Bacilliform virions of Canna yellow mottle virus (CaYMV)-Ap negatively stained with $1 \%$ uranyl acetate. Scale bar $=200 \mathrm{~nm}$. Arrows indicate putative badnavirus particles.
BBrMV in symptomatic plants (Fig. 8). Coinfection by both CaYMVAp and BBrMV in A. purpurata may produce more severe foliar symptoms than infections with either virus alone (Fig. 8). Mixed infections between badnaviruses and other viruses have been reported (Laney et al. 2012), including BSV and Cucumber mosaic virus (CMV) in banana (Brioso et al. 2000; Carnelossi et al. 2014), and Rubus yellow net virus and other unrelated viruses in Rubus spp. (Jones et al. 2002). CaYMV has also been found in mixed infections with CMV and a flexuous rod-shaped virus that may have been Bean yellow mosaic virus (BYMV) or Canna yellow streak virus (CaYSV) (Lockhart 1988). CaYMV has also been found in triple infections with BYMV and CaYSV (Chauhan et al. 2015).

In the family Caulimoviridae, the genera Badnavirus and Tungrovirus have bacilliform virions with particle lengths of 100 to $130 \times 30 \mathrm{~nm}$ (Hull et al. 2005), similar to what we found in A. purpurata preparations in this study. In this study, we determined the complete genome of CaYMV-Ap infecting A. purpurata, and found the sequence to be highly similar to the partial CaYMV sequences deposited in GenBank from previous studies (Marino et al. 2008; Kumari et al. 2014; Agneroh et al. 2015). Partial sequences of CaYMV isolates infecting Piper betel were also found to be highly homologous (96 to 99\% identity) to the published partial sequences of CaYMV (Kumari and Raj 2015). This result, together with our findings that CaYMV-Ap shares high sequence homology to the published partial sequences of CaYMV in Canna, indicate that CaYMV from different hosts can still share a high degree of similarity in their genome sequences. The complete genomic sequences of three badnavirus isolates from Canna spp., CaYMV isolate 0028 (accession KX066020.1), and defective isolates GAP5RC (accession KX255725.1) and GAP6RC (accession KX255726.1) were recently deposited into GenBank. In addition, two associated subviral elements EVS0036 (accession KX255723.1) and EVR00206 (accession KX255724.1) that code for a portion of a nonfunctional polyprotein (Wijayasekara et al. 2016) and that are very similar to all other previously reported CaYMV isolates have also recently been submitted to GenBank. However, those complete genome sequences of isolates 0028, GAP5RC, and GAP6RC share
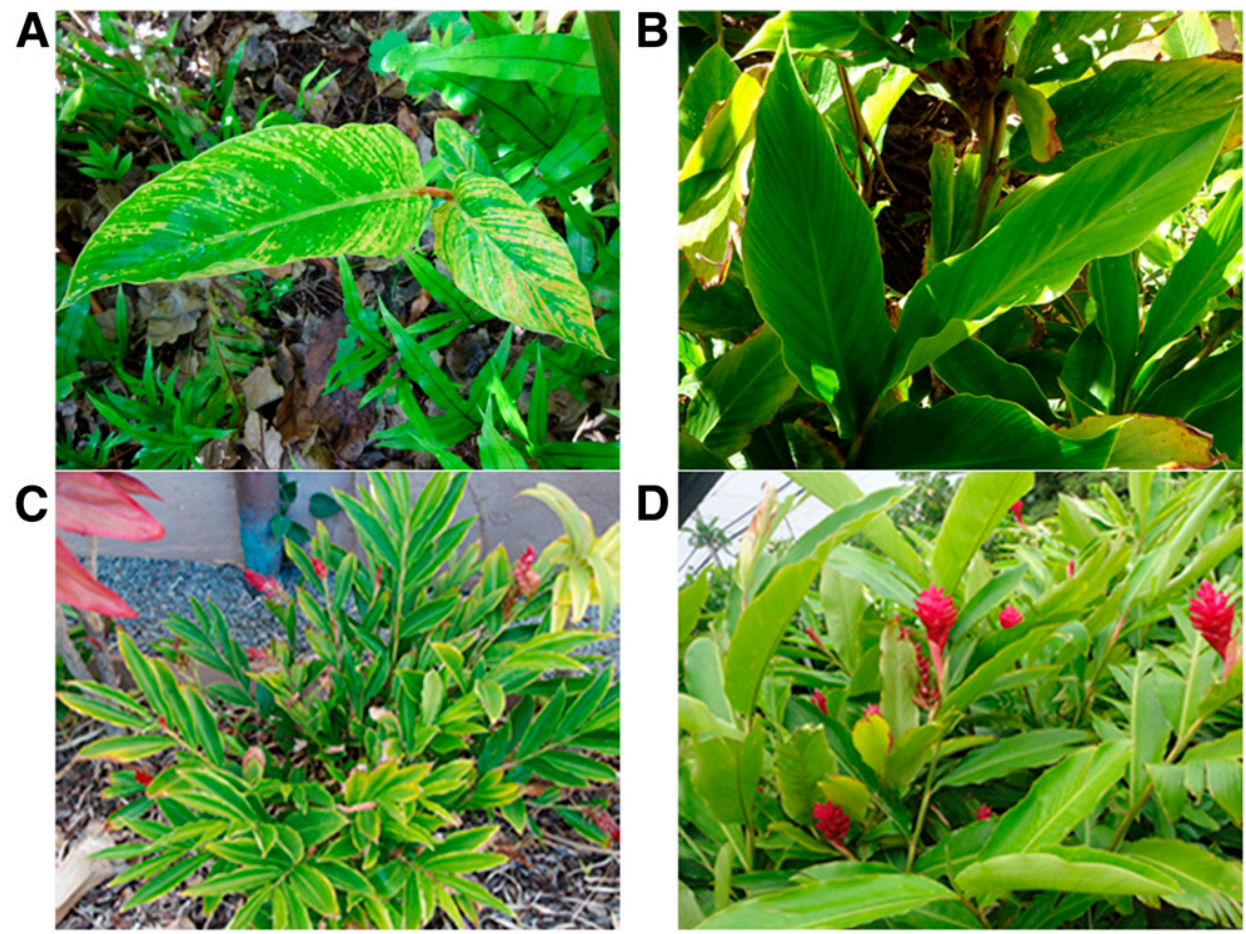

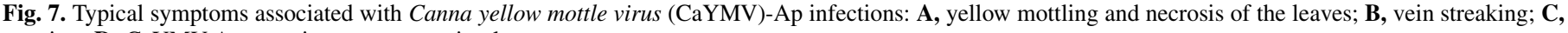
stunting; D, CaYMV-Ap-negative asymptomatic plants. 
less than $80 \%$ nucleotide sequence identity with the previously reported sequences from all other CaYMV isolates (Supplementary Fig. S2). In contrast, the complete genome sequence of the A. purpurata isolate reported in our study has a nucleotide sequence identity of $99 \%$ with the previously reported partial sequences of the RT-RNase $\mathrm{H}$ region from Canna spp. and P. betel. Because $<80 \%$ nucleotide identity in the RT$\mathrm{RNase} \mathrm{H}$ regions is a threshold criterion for species demarcation in the genus Badnavirus (Geering and Hull 2012), these three new genomic sequences appear to represent a Badnavirus species distinct from the previously reported CaYMV isolates and the A. purpurata isolate. This indicates that the variation in CaYMVs is similar to that among BSVs in banana and suggests that CaYMV is a group of species, as BSV is a group of species (Kumar et al. 2015). We have therefore decided to follow the nomenclatural system for BSVs and add the host plant name to the original virus isolate. We therefore propose the name CaYMVAp for the CaYMV isolate that occur in A. purpurata and suggest naming the CaYMV-0028 isolate from Canna indica as CaYMV-Ci (J. Verchot, personal communication).

BSV is known to integrate its genome sequences into the host genome (Geering et al. 2001). Other integrated badnaviruses, known as endogenous pararetroviruses (EPRVs), are integrated into the genomes of several plant species (Hany et al. 2014; Laney et al. 2012; Seal et al. 2014; Wang et al. 2014). The risk of introducing new viruses through infected plants is increased if information on episomal viruses and EPRVs is lacking for a host species or if the tools needed to detect episomal viruses or EPRVs are unavailable (Bousalem et al. 2009). Prior to our study, it was not known whether or not endogenous or episomal forms of CaYMV were present in plant hosts (Chauhan et al. 2015). Badnavirus particles have been found in Canna spp. infected with CaYMV (Momol et al. 2004). We have also found typical bacilliform particles in the same symptomatic leaves of $A$. purpurata (Fig. 6) that were used for the NGS experiments. Additionally, the episomal form of CaYMV-Ap could also be detected in A. purpurata using PCR and RT-PCR (Fig. 5). Most symptomatic plants that tested positive for CaYMV-Ap by PCR also tested positive for the virus using RT-PCR, while asymptomatic plants tested negative for CaYMV-Ap in both PCR and RT-PCR assays.

In a previous study of fig (Ficus carica), badnavirus-1, which is known to integrate into the fig genome, produced DNA fragments of multiple sizes in Southern hybridizations (Laney et al. 2012). However, we found no evidence of such fragments in digested

TABLE 2. Detection of Canna yellow mottle virus (CaYMV)-Ap in Alpinia purpurata collected from eight locations on the islands of Oahu and Hawaii

\begin{tabular}{ccccc}
\hline Island & Collection area & Site & Samples & Presence of CaYMV \\
\hline Oahu & Location 1 & 1 & 7 & 7 \\
& & 2 & 6 & 6 \\
& Location 2 & 1 & 3 & 3 \\
& 2 & 2 & 2 \\
& 3 & 2 & 2 \\
& 4 & 4 & 4 \\
& & 5 & 2 & 2 \\
& & 3 & 5 & 3 \\
& & 1 & 5 & 0 \\
& & 2 & 5 & 0 \\
& & 3 & 6 & 6 \\
& & 4 & 6 & 0 \\
& Location 3 & 1 & 5 & 0 \\
& Location 5 5 & 1 & 5 & 0 \\
Hawaii & Location 6 & 1 & 6 & 0 \\
& & 2 & 7 & 3 \\
& Location 7 & 1 & 7 & 0 \\
\hline
\end{tabular}

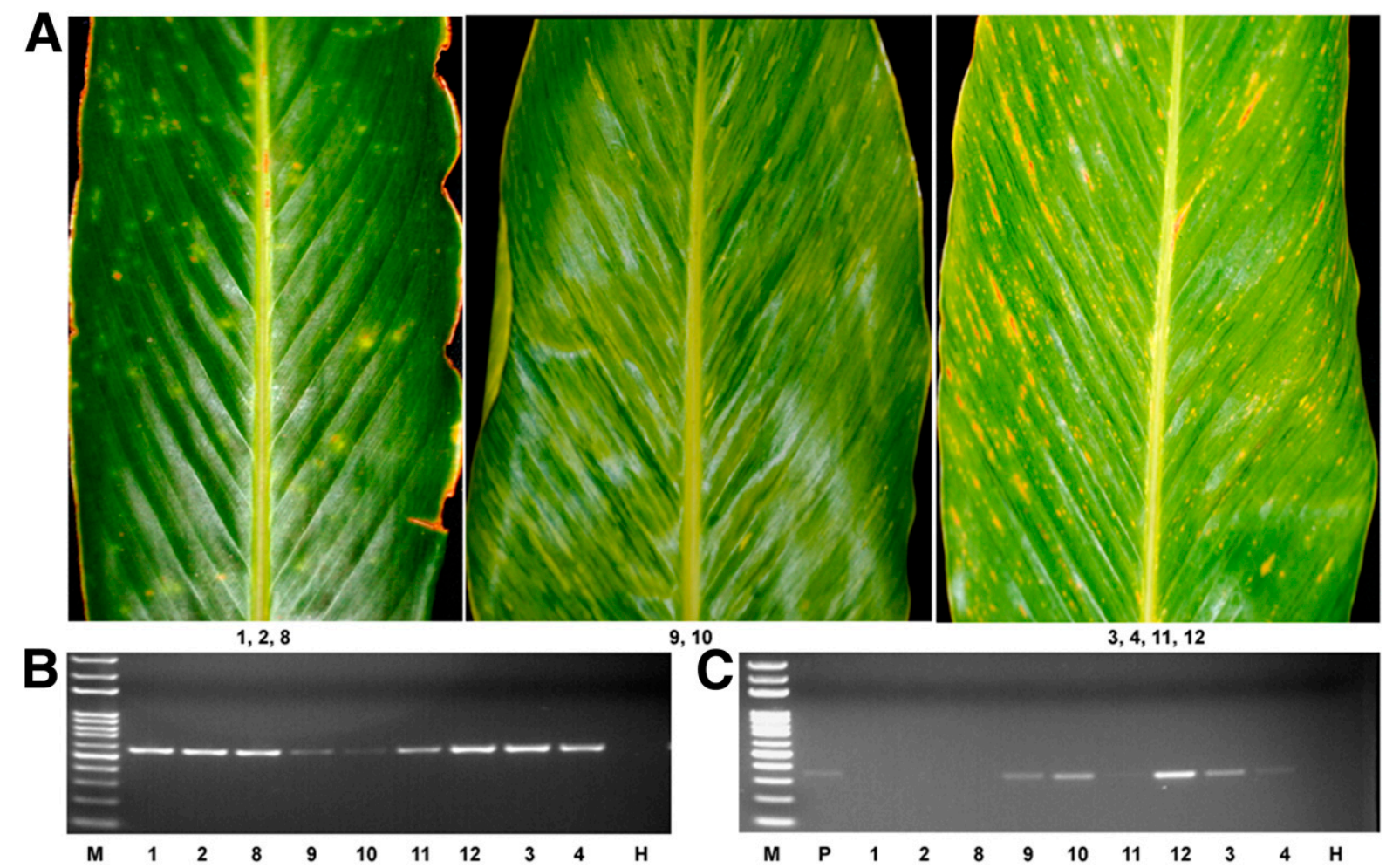

Fig. 8. Symptoms on leaves of Alpinia purpurata infected with Canna yellow mottle virus (CaYMV)-Ap, Banana bract mosaic virus (BBrMV), or both. A, Leaves collected from the University of Hawaii at Manoa, showing typical symptoms of CaYMV-Ap infections only (samples 1, 2, and 8), typical symptoms of BBrMV infections only (samples 9 and 10), and complex symptoms of both CaYMV-Ap and BBrMV infections (samples 3, 4, 11, and 12). B, CaYMV-Ap detected in A. purpurata leaves using specific primer pair CaYMV-3/4. All symptomatic leaves tested positive, but samples 9 and 10 were only weakly positive. C, BBrMV detected in A. purpurata leaves. Samples 1, 2, and 8 tested negative, while samples 3, 4, 9, 10, 11, and 12 tested positive, though sample 11 was only weakly positive. $\mathrm{M}=$ molecular weight marker; Numbers = ID of samples showing symptoms; $\mathrm{H}=$ samples from asymptomatic leaves; $\mathrm{P}=$ positive control $(\mathrm{BBrMV})$. 
genomic DNA from CaYMV-Ap-infected A. purpurata, suggesting that its sequences might not be integrated into the $A$. purpurata genome (data not shown). Symptomatic leaves (Fig. 5, samples 1 to 4) tested positive for CaYMV-Ap by PCR, but asymptomatic samples (Fig. 5, lane $\mathrm{H}$ ) collected from different plants at the same location were negative in our assay. We found similar results in samples collected from another location (Table 2, location 3), where only the six symptomatic samples from one of the four collecting sites tested positive for CaYMV-Ap using PCR. If CaYMV-Ap integrates into the host genome, the plants from all collection areas might have tested positive in PCR analyses. In addition, we completed the genome sequence of CaYMV-Ap from symptomatic A. purpurata plants and confirmed the sequence by Sanger sequencing of 12 overlapping PCR fragments; we did not identify any host sequences in the PCR products. However, more thorough studies are needed to conclusively determine if the integration of CaYMV sequences into its host genome can occur.

There are no vectors that are known to transmit CaYMV (Momol et al. 2004), but many badnaviruses are transmitted by mealybug species of the family Pseudococcidae (Harper et al. 2004). Examples include BSV transmitted by the citrus mealybug (Planococcus citri), the sugarcane mealybug (Saccharicoccus sacchari), and the pineapple mealybug (Dysmicoccus brevipes) (Kubiriba et al. 2001); ScBV transmitted to banana by S. sacchari (Lockhart and Autrey 1988); Piper yellow mottle virus (PYMV) transmitted by the mealybug, Ferrisia virgata (Bhat et al. 2003); and Dioscorea alata bacilliform virus transmitted efficiently both mechanically and by the mealybug P. citri (Kenyon et al. 2008). Badnaviruses can also be transmitted by insect vectors other than mealybugs. Rubus yellow net virus and Gooseberry vein banding virus, closely related phylogenetically (Fig. 4), are both transmitted by aphids (Bhat et al. 2016; Stace-Smith and Jones 1987). However, CaYMV-Ap is most closely related to the mealybug-transmitted badnaviruses ScBV, PBCoV, and BSV (Fig. 4), as well as PYMV (Lockhart et al. 1997). Several mealybug species are known to colonize A. purpurata including the citrus mealybug (Hansen et al. 1992). Therefore, mealybug species may be capable of vectoring CaYMV-Ap.

We have identified CaYMV-Ap in a new host $A$. purpurata in this study. In addition to the previously reported isolates infecting Canna spp., the isolates infecting P. betel are also very similar (97 to 98\% identity) to the CaYMV-Ap isolates (Kumari and Raj 2015). It is possible that the host range of CaYMV-Ap may eventually expand to include other important tropical plants. Additional studies on CaYMV-Ap are needed, including surveys of its distribution within the Hawaiian Islands and proactive screening of potential other plant hosts for the presence of this virus. These efforts will provide the information necessary to develop management strategies to mitigate the spread of CaYMV-Ap in Hawaii.

\section{ACKNOWLEDGMENTS}

This work was supported in part by grants from the National Natural Science Foundation of China (31300118) and the Guangdong Natural Science Foundation (2015A030312002). The research is also supported by the USDA National Institute of Food and Agriculture, Hatch HAW09025-H (1001478), and the USDA-Agricultural Research Service (58-5320-4-012). We thank B. Lockhart, H. Pappu, and J. Verchot for the helpful discussions of CaYMV nomenclature. The complete genome sequence reported in the present article has been deposited in GenBank database under accession number KU168312.

\section{LITERATURE CITED}

Agneroh, T. A., Bratsch, S. A., and Lockhart, B. E. 2015. First report of Canna yellow mottle virus in Kenya. Plant Health Progress. Published online. doi: 10.1094/PHP-BR-14-0037

Ahlawat, Y. S., Pant, R. P., Lockhart, B. E. L., Srivastava, M., Chakraborty, N. K., and Varma, A. 1996. Association of a badnavirus with citrus mosaic disease in India. Plant Dis. 80:590-592.

Bhat, A. I., Devasahayam, S., Sarma, Y. R., and Pant, R. P. 2003. Association of a badnavirus in black pepper (Piper nigrum L.) transmitted by mealybug (Ferrisia virgata) in India. Curr. Sci. 84:1547-1555.
Bhat, A. I., Hohn, T., and Selvarajan, R. 2016. Badnaviruses: The current global scenario. Viruses 8:177-205.

Bouhida, M., Lockhart, B., and Olszewski, N. 1993. An analysis of the complete sequence of Sugarcane bacilliform virus genome infectious to banana and rice. J. Gen. Virol. 74:15-22.

Bousalem, M., Durand, O., Scarcelli, N., Lebas, B. S. M., Kenyon, L., Marchand, J. L., Lefort, F., and Seal, S. E. 2009. Dilemmas caused by endogenous pararetroviruses regarding the taxonomy and diagnosis of yam (Dioscorea spp.) badnaviruses: Analyses to support safe germplasm movement. Arch. Virol. 154:297-314.

Brioso, P. S. T., Cordeiro, Z. J. M., Rezende, J. A. M., Kitajima, E. W., Pimentel, J. P., and Figueiredo, A. R. 2000. Mixed infection by cucumber mosaic (CMV) and banana streak (BSV) viruses in banana in Brazil. Summa Phytopathol. 26:254-257.

Carnelossi, P. R., Bijora, T., Facco, C. U., Silva, J. M., Picoli, M. H. S., Souto, E. R., and De Oliveira, F. T. 2014. Episomal detection of Banana streak $O L$ virus in single and mixed infection with Cucumber mosaic virus in banana 'Nanicão Jangada'. Trop. Plant Pathol. 39:342-346.

Chauhan, R. P., Wijayasekara, D., Webb, M. A., and Verchot, J. 2015. A reliable and rapid multiplex RT-PCR assay for detection of two potyviruses and a pararetrovirus infecting cannas. Plant Dis. 99:1695-1703.

Elbeaino, T., Giampetruzzi, A., De Stradis, A., and Digiaro, M. 2014. Deepsequencing analysis of an apricot tree with vein clearing symptoms reveals the presence of a novel betaflexivirus. Virus Res. 181:1-5.

Geering, A. D. W., and Hull, R. 2012. Genus Badnavirus in virus taxonomy classification and nomenclature of viruses. Pages 438-440 in: Ninth Report of the International Committee on Taxonomy of Viruses. M. Q. King, M. J. Adams, E. B. Carstens, and E. J. Lefkowitz, eds. Elsevier Academic Press, San Diego, CA.

Geering, A. D. W., Olszewski, N. E., Dahal, G., Thomas, J. E., and Lockhart, B. E. L. 2001. Analysis of the distribution and structure of integrated Banana streak virus DNA in a range of Musa cultivars. Mol. Plant Pathol. 2:207-213.

Hansen, J. D., Hara, A. H., and Tenbrink, V. L. 1992. Insecticidal dips for disinfesting commercial tropical cut flowers and foliage. Trop. Pest Manage. 38:245-249.

Hany, U., Adams, I. P., Glover, R., Bhat, A. I., and Boonham, N. 2014. The complete genome sequence of Piper yellow mottle virus (PYMoV). Arch. Virol. 159:385-388.

Harper, G., Hart, D., Moult, S., and Hull, R. 2004. Banana streak virus is very diverse in Uganda. Virus Res. 100:51-56.

Higgins, D., Thompson, J., Gibson, T., Thompson, J. D., Higgins, D. G., and Gibson, T. J. 1994. CLUSTAL W: Improving the sensitivity of progressive multiple sequence alignment through sequence weighting, position-specific gap penalties and weight matrix choice. Nucleic Acids Res. 22:4673-4680.

Hu, J. S., Gonsalves, A., Sether, D., and Ullman, D. E. 1993. Detection of pineapple closterovirus, a possible cause of mealybug wilt of pineapple. Acta Hortic. 334:411-416.

Hull, R., Geering, A., Harper, G., Lockhart, B. E., and Schoelz, J. E. 2005. Genus Badnavirus. Pages 392-396 in: Virus Taxonomy: 8th Report of the International Committee for Taxonomy of Viruses. C. M. Fauquet, M. A. Mayo, J. Maniloff, U. Desselberger, and L. A. Ball, eds. Elsevier Academic Press, San Diego, CA.

Idris, A., Al-Saleh, M., Piatek, M. J., Al-Shahwan, I., Ali, S., and Brown, J. K. 2014. Viral metagenomics: Analysis of begomoviruses by Illumina highthroughput sequencing. Viruses 6:1219-1236.

Illg, R. D., and Faria, R. T. 1995. Micropropagation of Alpinia purpurata from inflorescence buds. Plant Cell Tissue Organ Cult. 40:183-185.

Jacquot, E., Hagen, L., Jacquemond, M., and Yot, P. 1996. The open reading frame 2 product of Cacao swollen shoot badnavirus is a nucleic acidbinding protein. Virology 225:191-195.

Jones, A. T., McGavin, W. J., Geering, A. D. W., and Lockheart, B. E. L. 2002. Identification of Rubus yellow net virus as a distinct badnavirus and its detection by PCR in Rubus species and in aphids. Ann. Appl. Biol. 141: $1-10$.

Kenyon, L., Lebas, B. S. M., and Seal, S. E. 2008. Yams (Dioscorea spp.) from the South Pacific Islands contain many novel badnaviruses: Implications for international movement of yam germplasm. Arch. Virol. 153:877-889.

Kubiriba, J., Legg, J. P., Tushemereirwe, W., and Adipala, E. 2001. Vector transmission of Banana streak virus in the screenhouse in Uganda. Ann. Appl. Biol. 139:37-43.

Kumar, P. L., Selvarajan, R., Iskra-Caruana, M. L., Chabannes, M., and Hanna, R. 2015. Biology, etiology, and control of virus diseases of banana and plantain. Adv. Virus Res. 91:229-269.

Kumari, A., Kumar, S., and Raj, S. K. 2014. First report of Canna yellow mottle virus on Canna from India. New Dis. Rep. 29:9.

Kumari, A., and Raj, S. K. 2015. First report of Canna yellow mottle virus associated with yellow vein mosaic disease of Betel Vine (Piper betel) in India. Plant Dis. 99:1189. 
Laney, A. G., Hassan, M., and Tzanetakis, I. E. 2012. An integrated badnavirus is prevalent in fig germplasm. Phytopathology 102:1182-1189.

Lockhart, B. E. L. 1988. Occurrence of Canna yellow mottle virus in North America. Acta Hortic.: 69-72.

Lockhart, B. E. L., and Autrey, L. J. C. 1988. Occurrence in sugarcane of a bacilliform virus related serologically to banana streak virus. Plant Dis. 72: 230-233.

Lockhart, B. E. L., Kiratiya-Angul, K., Jones, P., Eng, L., De Silva, P., Olszewski, N. E., Lockhart, N., Deema, N., and Sangalang, J. 1997. Identification of Piper yellow mottle virus, a mealybug-transmitted badnavirus infecting Piper spp. in Southeast Asia. Eur. J. Plant Pathol. 103:303-311.

Marais, A., Faure, C., Couture, C., Bergey, B., Gentit, P., and Candresse, T. 2014. Characterization by deep sequencing of divergent Plum bark necrosis stem pitting virus (PBNSPaV) isolates and development of a broadspectrum PBNSPaV detection assay. Phytopathology 104:660-666.

Marais, A., Faure, C., Mustafayev, E., Barone, M., Alioto, D., and Candresse, T. 2015. Characterization by deep sequencing of Prunus virus T, a novel Tepovirus infecting Prunus species. Phytopathology 105:135-140.

Marino, M. T., Ragozzino, E., Lockhart, B. E. L., Miglino, R., and Alioto, D. 2008. First report of Canna yellow mottle virus (CaYMV) in Italy and in the Netherlands. Plant Pathol. 57:394.

Medberry, S. L., Lockhart, B. E. L., and Olszewski, N. E. 1992. The Commelina yellow mottle virus promoter is a strong promoter in vascular and reproductive tissues. Plant Cell 4:185-192.

Melzer, M. J., Borth, W. B., Sether, D. M., Ferreira, S., Gonsalves, D., and Hu, J. S. 2010. Genetic diversity and evidence for recent modular recombination in Hawaiian Citrus tristeza virus. Virus Genes 40:111-118.

Melzer, M. J., Sugano, J. S., Uchida, J. Y., Borth, W. B., Kawate, M. K., and $\mathrm{Hu}$, J. S. 2013. Molecular characterization of closteroviruses infecting Cordyline fruticosa L. in Hawaii. Front. Microbiol. 4:39.

Momol, M. T., Lockhart, B. E. L., Dankers, H., and Adkins, S. 2004. Canna yellow mottle virus detected in canna in Florida. Plant Health Prog. Published online. doi:10.1094/PHP-2004-0809-01-HN

Morris, T. J., and Dodds, J. A. 1979. Isolation and analysis of double-stranded RNA from virus-infected plant and fungal tissue. Phytopathology 69: 854-858.

Pappu, H. R., Druffel, K. B., and Eastwell, K. C. 2008. Canna yellow mottle virus in Canna spp. in Washington State. Plant Dis. 92:1136.

Paret, M. L., de Silva, A. S., Criley, R. A., and Alvarez, A. M. 2008. Ralstonia solanacearum race 4: Risk assessment for edible ginger and floricultural ginger industries in Hawaii. HortTechnology 18:90-96.
Seal, S., Turaki, A., Muller, E., Kumar, P. L., Kenyon, L., Filloux, D., Galzi, S., Lopez-Montes, A., and Iskra-Caruana, M.-L. 2014. The prevalence of badnaviruses in West African yams (Dioscorea cayensis-rotundata) and evidence of endogenous pararetrovirus sequences in their genomes. Virus Res. 186:144-154.

Stace-Smith, R., and Jones, A. T. 1987. Rubus yellow net virus. Pages 175-178 in: Virus Diseases of Small Fruits. R. H. Converse, ed. USDA Handbook 631.

Tamura, K., Peterson, D., Peterson, N., Stecher, G., Nei, M., and Kumar, S. 2011. MEGA5: Molecular evolutionary genetics analysis using maximum likelihood, evolutionary distance, and maximum parsimony methods. Mol. Biol. Evol. 28:2731-2739.

Wang, I. C., Sether, D. M., Melzer, M. J., Borth, W. B., and Hu, J. S. 2010. First report of Banana bract mosaic virus in flowering ginger in Hawaii. Plant Dis. 94:921.

Wang, Y., Cheng, X., Wu, X., Wang, A., and Wu, X. 2014. Characterization of complete genome and small RNA profile of Pagoda yellow mosaic associated virus, a novel badnavirus in China. Virus Res. 188:103-108.

Wijayasekara, D., Hoyt, P., Dunn, B., Gimondo, A., and Verchot, J. 2016. Threat to control Canna yellow streak virus; altered infectivity by associating with a sub-viral element of novel Canna yellow mottle virus. (Abstr.) Phytopathology 106(suppl.):S4.2.

Yamashita, S., Natsuaki, T., Doi, Y., and Yora, K. 1979. Ann. Phytopathol. Soc. Jpn. 45:484. (Title in Japanese).

Yamashita, S., Natsuaki, T., Doi, Y., and Yora, K. 1985. Canna yellow mottle virus, a non-enveloped small-bacilliform virus in Canna sp. Ann. Phytopathol. Soc. Jpn. 51:642-646.

Yang, I. C., Hafner, G. J., Revill, P. A., Dale, J. L., and Harding, R. M. 2003. Sequence diversity of South Pacific isolates of taro bacilliform virus and the development of a PCR-based diagnostic test. Arch. Virol. 148:1957-1968.

Zhang, J. X., Borth, W. B., Lin, B. R., Melzer, M. J., Shen, H. F., Pu, X. M., Sun, D. Y., and Hu, J. S. 2016. Deep sequencing of banana bract mosaic virus from flowering ginger (Alpinia purpurata) and development of an immunocapture RT-LAMP detection assay. Arch. Virol. 161:1783-1795.

Zheng, L., Wayper, P. J., Gibbs, A. J., Fourment, M., Rodoni, B. C., and Gibbs, M. J. 2008. Accumulating variation at conserved sites in potyvirus genomes is driven by species discovery and affects degenerate primer design. PLoS One 3:e1586. 